\title{
Editorial
}

\section{Towards pluralism in macroeconomics? 20th anniversary conference of the FMM research network}

As in recent years, the European Journal of Economics and Economic Policies: Intervention documents the contributions to the plenary sessions of the latest conference of the FMM research network, which took place on 20-22 October 2016 in Berlin, Germany. This year the Papers and Proceedings look back at 20 years of research within the network and macroeconomics in general. They also shed some light on potential avenues for research within the FMM framework in the future.

The evolution of the network started in Germany in the mid 1990s (cf. Hein/Priewe 2009 for the history of the FMM). At the time, Germany's economic development had been characterised by significant and rising unemployment, accompanied by increasingly constrained policy options due to globalisation and a strong focus on public debt sustainability and price stability from the late 1970 s onwards. Moreover, the theoretical foundations - leaning towards Monetarist and New Classical economics - had grown increasingly predominant since the 1980s and 1990s, particularly in Germany where alternative theoretical perspectives were almost completely marginalised. Somehow this situation had to change. The initiative was taken by Arne Heise, a senior researcher at the Institute for Economic and Social Research (WSI) at the German trade-union-related Hans Böckler Foundation. He brought together a group of German Keynesian academics and organised the first meeting in 1996. The discussions resulted in an application to the largest German research foundation (Deutsche Forschungsgemeinschaft) with the aim of establishing a Keynesian-oriented research centre as a counterpart to the mainstream at that time. ${ }^{1}$ Given the academic and political context of the time, it was not too surprising that the application was denied in 1997. However, further research in this field and an intensified cooperation between heterodox researchers was still urgently needed.

With support provided by the Hans Böckler Foundation, a network was founded to foster Keynesian, especially post-Keynesian, research and to stress the relevance of its economic policy concepts. Starting off as a small forum for exchange within a German-speaking community, it soon developed into a well-established international institution. Since its establishment it serves as a forum for macroeconomic issues and policy debates from alternative points of view to the dominant paradigm in economics. The network has a footing in the post-Keynesian camp but explicitly invites contributions from other heterodox schools of thought. Thematically it focuses on topics related to macroeconomics, financial markets, distribution and development. Initially, and due to its German-speaking origin, the network was named Forschungsnetzwerk Makroökonomie und Makropolitik (FMM). Later, the German name was replaced by its English equivalent Research Network Macroeconomics and Macroeconomic Policies, but the abbreviation was maintained. Since 2017, this inconsistency has been resolved by the new name Forum for Macroeconomics and Macroeconomic Policies (FMM). The FMM is not a membership organisation but consists of all

1. A revised German version of this application was later published as Heise et al. (1998). 
participants in the conferences and other activities of the network. A coordination committee takes care of all organisational issues and since 2016 has been represented by two speakers.

With the financial and organisational support of the Hans Böckler Foundation the first conference, on the renaissance of macroeconomics, was organised in October 1997. The proceedings of this conference were published and mark the beginning of a book series with Metropolis (Heise 1998). It was followed by 19 annual conferences (cf. the complete list of all conferences in the Appendix to this editorial), all again financially and organisationally supported by the Hans Böckler Foundation and, since 2005, especially the Macroeconomic Policy Institute (IMK) at the foundation. Each conference is devoted to a specific topic which is reflected in the plenary sessions, but parallel sessions are open to topics in the general scope of the network. Contributions to the theme of a conference are documented in the Papers and Proceedings, of which the first 15 were published with Metropolis and the more recent ones (since 2013) as special issues with this journal.

Very early on, the originally German-based network intensified contacts with researchers outside Germany. Especially Philip Arestis and Malcom Sawyer, who have participated in the conferences since the early 2000s, were tremendously important for strengthening the ties to the international community. From Germany, these ties were especially strengthened by Eckhard Hein, who took over the main responsibility for the organisation of the conferences from Arne Heise in 2001 and pushed the internationalisation of the network, although all other members of the coordination committee supported this development with combined efforts. The year 2005 marked the full internationalisation of the FMM when the conference was organised in collaboration with the Post Keynesian Economics Study Group (PKSG, UK) and the Association pour le Développement des Etudes Keynésiennes (ADEK, France) (for the proceedings, cf. Arestis et al. 2007; Fontana et al. 2006; Hein et al. 2006; Hein/Truger 2007). From 2005 onwards, topics and contributors fully reflect the internationality of the community of post-Keynesian researchers.

Over the years the structure of the conferences has changed responding to the increase in the number of presented papers but also the intention of the network to support young researchers. Nowadays, the conference lasts for three days and welcomes more than 300 international participants. Besides plenary and parallel sessions with around 130 presentations in sum, the conference's first day hosts introductory lectures (since 2010) on varying topics for an audience that is not already familiar with the theoretical orientations of the network. Moreover, graduate student sessions were introduced in 2006 to allow young researchers to present their work and get feedback from peers and seniors. Live streams and video documentations of the plenary sessions and intro workshops are available for more recent years.

Apart from the main event, the FMM regularly organises smaller workshops and conferences on current macroeconomic policy issues, often in close cooperation with other networks and organisations. As part of its ambition to promote young scholars, in 2008 the FMM established a summer school on Keynesian macroeconomics that has (since 2009) been run every uneven year in the first week of August in Berlin. An outcome of the first summer schools was a textbook on post-Keynesian economics, edited by Hein and Stockhammer (2011).

In more recent years, the FMM has leveraged its increasing popularity and successfully invited leading open-minded mainstream economists to discuss the potential for paradigm change within economics. At the same time, the network has allied with student initiatives campaigning for a more pluralist economics to organise joint events.

'The times they are a-changin', as the 2016 Nobel Prize winner of literature, Robert A. Zimmermann, reminds us, but in economics progress seems to be slow. Even today there is only a limited leeway for post-Keynesian and heterodox ideas in academia and policy debates. This is why pluralism in economics is not only the topic of the 20th and latest 
conference which we document in this issue; it has been the underlying topic of all FMM conferences. However, the financial market crisis and the subsequent crisis of the euro area have strongly emphasised the unease with conventional wisdom and the dominant policy concepts as represented by the New Keynesian New Consensus Model (cf. Arestis 2011 for this modelling approach). It is this unease that calls more than ever for different perspectives on economic issues. A variety of approaches is required to avoid the one-sided, erroneous dominance of mainstream theory of the past.

The papers of the FMM 20th anniversary conference reflect upon the origins and developments of the network over the years. They also look forward to new challenges because research in macroeconomics and macroeconomic policies in a dynamic world characterised by complexity and uncertainty can never come to an end.

The first paper, by Eckhard Hein, reviews the theoretical development of the postKeynesian approach, as represented in the network, and differentiates post-Keynesian thinking from the orthodox New Consensus but also from other heterodox schools of thought. Against the background of the 20th anniversary of FMM, more space than usual was accorded to this paper.

The unease with the still-dominant modelling concept in economics is also addressed by the next two contributions, respectively by Roger Farmer and Michael Roos. Both of them present a positive research agenda that avoids the deficiencies of the mainstream approach. But they take quite different directions.

Roger Farmer proposes, as the title of his article nicely summarises, a 'Post-Keynesian dynamic stochastic general equilibrium theory'. In order to be able to influence the mainstream discussion he suggests continuing to use dynamic stochastic general equilibrium (DSGE) models but to make some crucial changes to the substance of DSGE. Markets are inherently inefficient, and this inefficiency can be traced back to the simple fact that people who are not yet born cannot participate in the formation of expectations. Making this explicit in a DSGE model substantiates two key Keynesian propositions, even though the framework is still characterised by a general equilibrium: first, that animal spirits (beliefs) drive business cycles and change aggregate demand; and, second, that involuntary unemployment exists and persists.

Michael Roos analyses the influence of behavioural assumptions on macroeconomics. For him, an implantation of behavioural insights into mainstream DSGE models will necessarily lead to insufficient results if the assumption of a representative agent is not dropped. He suggests a combination of complexity economics with agent-based modelling in order to increase the level of realism and relevance in macroeconomic models. Thus, he stresses the heterogeneity of interacting agents with bounded rationality and the prevalence of disequilibria.

In-depth analyses of two major debates and advances in post-Keynesian theory are provided by the two subsequent papers.

A first important debate in post-Keynesian economics that was reflected in many panels at the FMM conferences is that which concerns the impact of changes in income distribution on demand (wage-led versus profit-led demand regime). Marc Lavoie, one of the foremost postKeynesian scholars, gives an overview of the debate. He goes back to the origins of the debate and highlights the economic policy debate that it relates to. Does it make sense for progressive economists to demand higher wage growth, or would that ultimately hurt workers, because capitalists need profits in order to invest? Lavoie highlights that the Marxist profit-squeeze analysis assumed a profit-led demand regime and implied a futility of pro-labour distributional changes. In contrast post-Keynesian have highlighted that, with underutilised capacity, higher wages can have a positive effect on overall demand (they assume a wage-led demand regime).

Maria Nikolaidi is one of the promising young scholars working in the post-Keynesian tradition. She gives a survey of recent attempts to model Minsky's argument of financial instability and financial cycles. Hyman Minsky had long highlighted the financial origins 
of economic cycles and his work has met great interest recently. There are several attempts to formalise his arguments and Nikolaidi gives a masterful survey of a difficult literature. She identifies several families of Minsky models that have integrated Minsky debt cycles with Kaleckian, Kaldorian or Goodwinian macroeconomic models, as well as those that have speculative asset price cycles at their core.

The final three papers are all concerned with explicit pluralist alternatives to mainstream economics and strategies to overcome the neoclassical mainstream dominance.

In his paper, Sebastian Dullien discusses the merits and risks of heterodox economists using mainstream economic models, in particular DSGE models, to promote economic (policy) conclusions found in post-Keynesian economic thought, such as large fiscal multipliers, the importance of distributional issues for macroeconomic stability, and the role of endogenous money creation. He argues that using these models may, on the one hand, help heterodox researchers to communicate with mainstream economists and help to further one's personal academic career, but that, on the other hand, such a strategy comes at the risk of having to accept other, very questionable policy conclusions and of stabilising the use of the DSGE models in mainstream economics, hence potentially delaying a Kuhnean-type 'scientific revolution' in macroeconomics.

In their paper, Andreas Dimmelmeier, Frederick Heussner, Andrea Pürckhauer and Janina Urban present a comparative approach to economics which serves as the intellectual basis for the online learning platform Exploring Economics (exploring-economics. $\mathrm{com} / \mathrm{en} /$ ). Their approach is committed to a vision of theoretical and methodological pluralism and is grounded in concepts derived from biology, the history of economic thought, the philosophy of science and international political economy. The resulting conceptualisation offers a tool for the teaching of pluralist economics according to a contending perspectives method, emphasising the different underlying assumptions and meta-theoretical positions of some of the most prominent schools of thought in economics.

In her paper, Irene van Staveren presents a pluralist teaching method in macroeconomics and explains it with examples. She demonstrates why pluralist macroeonomics teaching is important and that it is feasible to do so even at the introductory level. She demonstrates how it can be achieved with reference to five key economic theories: social economics, institutional economics, feminist economics, post-Keynesian economics and neoclassical economics. She briefly summarises how teaching can be done on topics such as the macroeconomic flow, economic growth, trade, poverty and well-being, and money.

Sebastian Gechert Macroeconomic Policy Institute, Hans Böckler Foundation, Düsseldorf, Germany.

Torsten Niechoj Rhine-Waal University of Applied Sciences, Kamp-Lintfort, Germany.

Engelbert Stockhammer Kingston University London, UK.

Achim Truger

Berlin School of Economics and Law and Senior Research Fellow at Macroeconomic Policy Institute, Hans Böckler Foundation, Düsseldorf, Germany.

Andrew Watt

Macroeconomic Policy Institute, Hans Böckler Foundation, Düsseldorf, Germany 


\section{REFERENCES}

Arestis, P. (2011): Keynesian economics and the New Consensus in macroeconomics, in: Hein, E., Stockhammer, E. (eds), A Modern Guide to Keynesian Macroeconomics and Economic Policies, Cheltenham, UK and Northampton, MA: Edward Elgar, 88-111.

Arestis, P., Hein, E., Le Heron, E. (eds) (2007): Aspects of Modern Monetary and Macroeconomic Policies, Basingstoke, UK: Palgrave Macmillan.

Fontana, G., Gnos, C., Truger, A. (eds) (2006): The 'New Monetary Policy': a critical appraisal, Special Issue, in: Intervention. Journal of Economics, 3(2).

Hein, E., Priewe, J. (2009): The Research Network Macroeconomics and Macroeconomic Policies (FMM): Past, Present and Future, in: Intervention. European Journal of Economics and Economic Policies, 6(2), 166-173.

Hein, E., Stockhammer, E. (eds) (2011): A Modern Guide to Keynesian Macroeconomics and Economic Policies, Cheltenham, UK and Northampton, MA: Edward Elgar.

Hein, E., Truger, A. (eds) (2007): Money, Distribution and Economic Policy: Alternatives to Orthodox Macroeconomics, Cheltenham, UK and Northampton, MA: Edward Elgar.

Hein, E., Heise, A., Truger, A. (eds) (2006): European Economic Policies: Alternatives to Orthodox Analysis and Policy Concepts, Marburg: Metropolis.

Heise, A. (ed.) (1998): Renaissance der Makroökonomik, Marburg: Metropolis.

Heise, A., Kromphardt, J., Priewe, J. (1998): Alternative Konzeptionen der makroökonomischen Politik im Spannungsfeld von Arbeitslosigkeit, Globalisierung und hoher Staatsverschuldung, in: Eicker-Wolf, K., Käpernick, R., Niechoj, T., Reiner, S., Weiß, J. (eds), Die arbeitslose Gesellschaft und ihr Sozialstaat, Marburg: Metropolis, 95-134.

\section{APPENDIX: COMPLETE LIST OF FMM CONFERENCES}

1st FMM Conference: Alternativen der makroökonomischen Politik im Spannungsfeld von Arbeitslosigkeit, Globalisierung und hoher Staatsverschuldung, Berlin, Germany, 1997

2nd FMM Conference: Perspektiven der Makropolitik zwischen Nationalstaat und Europäischer Union, Düsseldorf, Germany, 1998

3rd FMM Conference: Neue Architektur der Weltwährungsordnung, Berlin, Germany, 1999

4th FMM Conference: USA - Dekonstruktion eines Modells?!, Berlin, Germany, 2000

5th FMM Conference: Eine andere Geldpolitik für mehr Wachstum und Beschäftigung in Europa?, Berlin, Germany, 2001

6th FMM Conference: Neukeynesianismus - der neue wirtschaftspolitische Mainstream?, Berlin, Germany, 2002

7th FMM Conference: Finanzpolitik in der Kontroverse, Berlin, Germany, 2003

8th FMM Conference: Löhne, Verteilung und Wachstum, Berlin, Germany, 2004

9th FMM Conference: Macroeconomics and macroeconomic policies - alternatives to the orthodoxy, in co-operation with the Post Keynesian Economic Study Group (UK) and the Association pour le Développement des Études Keynésiennes (FR), Berlin, Germany, 2005

10th FMM Conference: European integration in crisis, Berlin, Germany, 2006

11th FMM Conference: Finance-led capitalism? Macroeconomic effects of changes in the financial sector, Berlin, Germany, 2007

12th FMM Conference: Macroeconomic policies on shaky foundations - whither mainstream economics?, Berlin, Germany, 2008

13th FMM Conference: The world economy in crisis - the return of Keynesianism?, Berlin, Germany, 2009 
14th FMM Conference: Stabilising an unequal economy? Public debt, financial regulation, and income distribution, Berlin, Germany, 2010

15th FMM Conference: From crisis to growth? The challenge of imbalances, debt, and limited resources, Berlin, Germany, 2011

16th FMM Conference: The state of economics after the crisis, Berlin, Germany, 2012

17th FMM Conference: The jobs crisis: causes, cures, constraints, Berlin, Germany, 2013

18th FMM Conference: Inequality and the future of capitalism, Berlin, Germany, 2014

19th FMM Conference: The spectre of stagnation? Europe in the world economy, Berlin, Germany, 2015

20th FMM Conference: Towards pluralism in macroeconomics? 20th anniversary conference of the FMM Research Network, Berlin, Germany, 2016 